\title{
"We are all (potential) plurilinguals": Plurilingualism as an overarching, holistic concept
}

\author{
Enrica Piccardo \\ enrica.piccardo@utoronto.ca \\ OISE - UNIVERSITY OF TORONTO
}

\begin{abstract}
In spite of the spark that plurilingualism has given throughout Europe and beyond to the idea that linguistic and cultural diversity is an asset rather than an obstacle, the term plurilingualism itself has not frequently been used in the English-speaking world. Beginning with an analysis of this issue, this paper aims to help readers better understand the nature of the concept of plurilingualism and reflect on its social and educational value. To do so, it firstly presents the term from a historical and comparative perspective in relation to other terms used in the English-speaking literature. It then moves on to explain the crucial difference between plurilingualism and multilingualism, thus introducing the notion of dynamic repertoire and its underlying theoretical perspective. Finally, the article introduces the descriptors for plurilingual and pluricultural competence from the newly released CEFR Companion Volume, together with the potential for these descriptors to facilitate mediation and plurilanguaging among learners and to foster a new, open, and positive attitude towards linguistic and cultural diversity in language classes.
\end{abstract}

Key words: plurilingualism, multilingualism, plurilanguaging, CEFR, mediation

\section{Résumé}

Malgré le rôle déclencheur que le plurilinguisme a joué en Europe et audelà de l'idée que la diversité linguistique et culturelle est un atout plutôt qu'un obstacle, le terme correspondant en anglais à «plurilinguisme »'plurilingualism' - n'est pas utilisé fréquemment dans le monde anglophone. Partant d'une analyse de ce constat, cet article vise à aider le lecteur à mieux comprendre la nature du concept de plurilinguisme et à réfléchir sur ses atouts. Pour cela, il présente d'abord le terme en partant d'une perspective historique et comparative par rapport à d'autres termes qui sont utilisés dans la littérature scientifique de langue anglaise. Ensuite il se tourne vers l'explication de la différence profonde entre plurilinguisme 
and multilinguisme, ce qui permet d'introduire la notion de répertoire dynamique et la perspective théorique qui l'informe. Enfin, l'article introduit les descripteurs de la compétence plurilingue et pluriculturelle du nouveau CECR Volume complémentaire et présente les raisons pour lesquelles ces descripteurs peuvent favoriser la médiation et le processus de 'plurilanguaging' de la part des apprenants et ainsi favoriser une attitude nouvelle et ouverte envers la diversité linguistique et culturelle dans les classes de langue.

Mots-clés : plurilinguisme, multilinguisme, plurilanguaging, CECR, médiation

\section{Plurilingualism, not just a terminological option}

Plurilingualism, the concept that tries to capture the dynamic and developing linguistic repertoire of an individual user/learner, was introduced to language education in the Common European Framework of Reference for Languages (henceforth CEFR; Council of Europe, 1996, 2001) and further refined in the recently released CEFR Companion Volume (henceforth CEFRCV) (Council of Europe, 2018a). ${ }^{1}$ The international, mainly Swiss-based, plurilingual team that authored the CEFR in the early 1990s borrowed the term from the French plurilinguisme, although the term itself has a longer history in linguistics, as developed in other Romance languages (e.g., the Italian term plurilinguismo used by de Mauro in 1977). Switzerland, with its institutional multilingualism and the plurilingual attitudes of individuals used to drawing upon their partial competences in different languages in their day-to-day interactions, was the cradle for a reflection on plurilingualism (e.g., Berthoud, 1996; Coste \& Hebrard, 1991; Lüdi \& Py, 2003, 2009). In addition, this was a period that also saw an increase in studies into bilingualism and the development of the concepts of "multicompetence" (the characteristic of people with more than one language, which cannot be equated to the sum of two monolingual competences [Cook, 1991]), and "translanguaging" (a form of dual language classroom scaffolding in the context of the teaching of Welsh [Williams, 1996]). In this context the introduction of plurilingualism to the domain of second/foreign languages as a broad and overarching concept distinct from multilingualism was a forward-looking choice, with the concept appearing fully-fledged in the second draft of the CEFR in 1996 (Council of Europe, 1996), accompanied by a CEFR-related study (Coste, Moore, \& Zarate, 2009).

\footnotetext{
${ }^{1}$ The Council of Europe is a 47-member pan-national body concerned with human rights, language rights, and the protection of minorities. It has been active in language education at a policy level since the 1960s (Trim, 2012) and, in particular, promotes plurilingual, intercultural education (Beacco \& Byram, 2007).
} 
The term "plurilingualism" describes a process of dynamic, creative "languaging" across the boundaries of language varieties. It also refers to the theory underlying this process, as well as the relevant language policy aims and related methodological approaches. I discuss below the distinction between plurilingualism and multilingualism. Plurilingualism represents a complex phenomenon that transcends language boundaries both in language use (e.g., Berthoud, Grin, \& Lüdi, 2013; Canagarajah, 2009; Canagarajah \& Liyanage 2012; Dacrema, 2012; Lüdi, 2014, Lüdi \& Py, 2009) and in language education (e.g., Beacco et al., 2016; Coste, 2014; Piccardo, 2017). It calls for a completely new, kaleidoscopic, complex vision, where terms such as "linguistic (and cultural) repertoire" and "linguistic (and cultural) trajectory" act as conceptual guiding tools (see Piccardo \& North, 2019, for further discussion).

In spite of the impact that the concept has had on innovation in language education in Europe, as we discuss below, plurilingualism both as a term and as a concept is still not as widely used in the dominant English-speaking academic culture as one would expect. Over the last 25 years, plurilingualism, and its corresponding terms in various languages (e.g., French, Italian, German, Spanish) has become a widely used referential concept for language policy and language pedagogy in Europe. It is therefore strange that such a useful term is not much used in English-medium academic literature. Several scholars did indeed initially adopt the term (e.g., Canagarajah \& Liyanage, 2012; Cenoz \& Gorter, 2013; García, Bartlett, \& Kleifgen, 2007; García \& Kleifgen, 2010; García \& Sylvan, 2011). García and Kleifgen, for example, talk of "dynamic plurilingual education" (2010, p. 391) and go on to say that they "follow the use of the Council of Europe in reserving the term 'plurilingual' for the complex language practices of individuals, whereas using 'multilingual' to signal the language practices of classrooms, geographic or political areas, or groups" (p. 391). However, the use of the term "multilingualism' to refer to all forms of linguistic plurality has remained centre stage and scholars writing in English have decided to use the term "multilingualism" even when they recognize the conceptual differences between plurilingualism and multilingualism (Cenoz \& Gorter, 2013). ${ }^{2}$

Instead of a serious consideration of the concept of plurilingualism and its distinctive characteristics, what we witness is a continuous further definition of the terms bi/multilingualism. Scholars repeatedly modulate these terms

\footnotetext{
${ }^{2}$ In the European context, the choice by the European Commission to use the term "multilingualism" for both concepts of multilingualism and plurilingualism, as they are defined by the Council of Europe, has contributed to the overlooking of the conceptual differences of the two terms, and has thus been detrimental to the dissemination of the term "plurilingualism".
} 
with adjectives in order to try and capture the dynamic and complex nature of the process - already captured by the terms plurilingualism, and plurilingual and pluricultural competence. Examples include: holistic view of multilingualism (Cenoz, 2013); active bilingualism, active multilingualism (Cummins, 2017); dynamic model of multilingualism (Herdina \& Jessner, 2002); and integrated multilingual model (MacSwan, 2017). At the same time, the conceptual domain of the term "translanguaging", a term which had been developed to describe a pedagogical practice in a specific bilingual educational context (Lewis, Jones, \& Baker, 2012; Williams, 1996), is regularly extended (e.g., García, 2012; García \& Otheguy, 2014; García \& Wei, 2014; Otheguy, García, \& Reid, 2015; Vogel \& García, 2017), not only as one would naturally expect to better explain the rich pedagogical practices that multilingual classes call for, but to assert it as a theoretical dimension. Interestingly, translanguaging now itself has started to be modulated into two versions, a strong one and a weak one (García \& Lin, 2017), an external perspective versus an internal perspective (Vogel \& García, 2017). In addition, alongside the extension and modulation of the terms multilingualism and translanguaging, we have also seen a proliferation of various "-isms" that aim to capture some features of dynamic language use. In referring to these developments, Marshall \& Moore (2018) talk of "an array of lingualisms" (p. 19) and discuss the dangers of various misinterpretations of plurilingualism. They point out that these terms tend to focus on one or two aspects of plurilingualism, but fail to capture its holistic and overarching nature.

Terminological debate marks the vitality of the research in the domain of bi/multilingualism, but this debate, laudable in itself, seems to have overlooked the academic reflection around the term "plurilingualism" over the last two decades in the non-anglophone literature (for a synthesis, see Bigot, Bretegnaier, \& Vasseur, 2013; Moore \& Gajo, 2009), which is in itself somewhat at odds with the idea of valuing diversity in academic discourse. As I will attempt to show, the concept of plurilingualism is an enriching one that offers great potential from both societal and educational viewpoints, and is not interchangeable with other notions. This is particularly the case with regard to the valorisation of, openness to and respect for non-dominant languages together with the cultures and the rich and diverse human knowledge and experience that they represent.

\section{Plurilingualism and plurilingual competence}

The CEFR put forward plurilingualism in order to clearly convey a constructive view of language diversity and at the same time to overcome the strict binary view of bilingualism. Plurilingualism is presented as a concept that helps to make sense of the complex nature of language development of individuals seen 
as social agents, who interact in various ways with their environment. For the CEFR (Council of Europe, 2001):

plurilingual competence is the ability to use languages for the purposes of communication and to take part in intercultural interaction, where a person, viewed as a social agent, has proficiency of varying degrees, in several languages, and experience of several cultures. This is not seen as the superposition or juxtaposition of distinct competences, but rather as the existence of a complex or even composite competence on which the user may draw. (p. 168)

In a recent guide to developing plurilingual and intercultural curricula, Beacco et al. (2016) define plurilingualism as follows:

Plurilingual competence is defined as the ability to use a plural repertoire of linguistic and cultural resources to meet communication needs or interact with people from other backgrounds and contexts, and enrich that repertoire while doing so. The repertoire consists of resources which individual learners have acquired in all the languages they know or have learned, and which also relate to the cultures associated with those languages ... The plurilingual perspective centres on learners and the development of their individual plurilingual repertoire, and not each specific language to be learnt. (p. 23)

As the recently published CEFR Companion Volume puts it (Council of Europe, 2018a): "Plurilingualism can ... be considered from various perspectives: as a sociological or historical fact, as a personal characteristic or ambition, as an educational philosophy or approach, or - fundamentally — as the socio-political aim of preserving linguistic diversity" (p. 28). Plurilingualism is closely linked to pluriculturalism, and in the CEFR they in fact appear together throughout under the term "plurilingual and pluricultural competence". This is seen as a dynamically developing, unbalanced, partial competence that should also be a major educational aim (Beacco \& Byram, 2007).

A series of pedagogical approaches (e.g., Candelier et al., 2010; Corcoll López \& Gonzáles-Davies, 2016; Del Barrio, 2015; Neuner-Anfindsen $\&$ Meima, 2016), have trailblazed the way plurilingualism can inform classroom practice. Plurilingual approaches are sometimes referred to as "pluralistic approaches", "which use teaching/learning activities involving several (i.e. more than one) varieties of languages or cultures ... to be contrasted with approaches which could be called "singular" in which the didactic approach takes account of only one language or a particular culture, considered in isolation" (Candelier et al., 2010, p. 5).

A plurilingual approach stimulates curiosity about languages and cultures (Byram, 2008), an ability to see (and to look for) the links between languages, and between language and culture (Auger, 2010), as well as an increased awareness of how languages - including one's own mother tongue(s) - operate, en- 
gendering a new feeling for the place and role of different registers and varieties (Galante, 2018; Piccardo, 2013). In fact, as the CEFR highlights, in the experience of plurilingualism and pluriculturalism, pre-existing sociolinguistic and pragmatic competences are both exploited and further developed, and an increased perception of the specificities of different languages is developed, leading ultimately to an increased ability to learn languages. In the plurilingual vision, partial competence - e.g., a knowledge of some words and expressions; fluency without so much accuracy or vice versa; an ability to understand but not to produce - is valued as a natural, temporary state in the developing linguistic (and cultural) repertoire of each individual.

The notion of plurilingualism is fundamentally a dynamic, flexible one (Beacco \& Byram, 2007; Piccardo \& Puozzo, 2015; Stratilaki, 2005). Languages are fluid entities within which each of us constructs their own holistic and unique cartography (Kramsch, 2009), their "idiolect" (Otheguy et al., 2015). In a plurilingual approach, user/learners are encouraged to think in terms of their holistic language repertoire, made up of their different languages and varieties, (inter)cultural and linguistic encounters. Users/learners are then required to reflect on the insights, competencies, and strategies that constantly contribute to this fluid and magmatic process. This reflection enables a better perception of the limitation of boundaries and the existence and value of "in-between spaces" (Furlong, 2009). Navigating in-between spaces is closely related to Kramsch's concept of "symbolic competence" (2009). This competence both requires and develops agency from the individual who uses (and learns) languages, as well as their capacity to perceive affordances (Käufer \& Chemero, 2015, van Lier, 2004). Furthermore, opening up to hybrid spaces and crossing boundaries is conducive to creativity (Furlong, 2009; Piccardo, 2017). Crucially, it is also key to being comfortable with the complex and everchanging linguistic and cultural identities of oneself and others and, above all, to being aware of and at ease with further developing one's own identity.

The symbolic meanings accumulated through experiences of the mind and body constitute a kind of map (Kramsch, 2009) that informs individuals' view of the world and helps them to construct a new plurilingual and pluricultural identity. A person is plural, as Lahire (1998) well explained: it is not just a question of roles, behind which a substantial unity exists, but rather the idea that individuals are the complex products of multiple processes of socialisation. The linear view of a personal core - an inner self independent from any context - is not only limited but a possible source of malaise. Thus, the open, dynamic, and multiple lens that plurilingualism offers can represent an embracing, liberating perspective that fosters individuals' agency.

The creative and critical nature of plurilingualism has become even clearer with the recent CEFR Companion Volume (Council of Europe, 2018a) for which 
new descriptors for plurilingual and pluricultural competence and the related concept of mediation have been developed. This new development and the underlying theoretical framework are presented in North and Piccardo (2016). Plurilingualism is closely linked to the notion of mediation, which implies a complex dynamic vision of language learning and use, with a simultaneous implication of the cognitive, social, and emotional dimension of individuals engaged in plurilanguaging (Piccardo, 2017), as we will see later in this article.

\section{Multilingualism, plurilingualism, and related terms}

The CEFR clearly distinguishes plurilingualism from multilingualism, confining the latter to: "the knowledge of a number of languages, or the co-existence of different languages in a given society" (Council of Europe, 2001, p. 4). The mere presence of different languages in any given context, including educational institutions, is not per se a gauge of any form of mixing or meshing, nor even of reciprocal interest or openness to implementing any pluralistic approach. Cummins (2007) borrowed the term "the two solitudes" from the novel by Hugh MacLennan (1945) and repurposed it to illustrate the problem of teaching languages through a monoglossic lens. In the domain of cultures, the French term communautarisme comes with the negative connotation of different communities living in silos, at best ignoring each other. It would be naïve to deny that, in view of political developments in many countries, we are walking on thin ice when it comes to linguistic and cultural diversity. As Baumann (2000) points out, we are faced with a big opportunity but also with a serious risk according to the socio-political perspective that prevails. The choice of the CEFR to use the two Latin prefixes multi- and pluri- as conceptual springboards is thus significant: it was a decision to tackle this socio-political problem upfront. The choice was to use the two terms to highlight the distinction between two different perspectives: using the prefix "multi-" to stress the multiplication of singularities - adding together a series of elements like numbers in a multiplication, or people in a multitude — while using "pluri-" in a more holistic way, with the idea of valuing — and building on - plurality, of considering embedded difference. This subtle distinction would have a leverage effect in helping to conceptualize the fundamental difference between the two opposite visions of linguistic and cultural diversity: pureness or richness, rejection of otherness or empathy, living side by side or living together, tolerance or active interest (Balboni, 2015).

Needless to say, by stressing the addition of different elements, multilingualism also inevitably puts an emphasis on the boundaries between languages, which is one reason scholars wishing to focus on a dynamic perspective feel the need to modulate the term. Plurilingualism and pluriculturalism, on the contrary, have been conceptualized since their appearance to stress permeabil- 
ity and porosity of languages and cultures, the dynamic moulding of one's repertoire, the flow of the construction of plurilingual and pluricultural competence. Conflating the constructs underlying bilingualism, multilingualism, and plurilingualism as some scholars do (e.g., García \& Wei, 2014; Vogel \& García, 2017), by saying that all three terms consider languages as autonomous in relation to one another, means denying the dynamic nature of plurilingualism by reducing it to a simple addition of languages. It means disregarding the core idea that plurilinguals have one specific, complex, and composite competence, one linguistic repertoire that does not consist of the sum of languages or parts thereof, but that consists of resources that each individual has acquired in and through the languages and cultures that they have encountered in their personal trajectory. At the core of plurilingualism are "learners and the development of their individual plurilingual repertoire, and not each specific language to be learnt" (Beacco et al., 2016, p. 23). Finally, plurilingualism does not apply only to individuals who have some proficiency in different languages, but also to individuals who consider themselves as monolinguals (Piccardo, 2013; Wandruska, 1979), as every language is itself a compositum of different varieties, sociolects, and borrowings, and is intrinsically dynamic in its constant change. Denying these core characteristics means disregarding not only the detailed explanation of the plurilingualism construct in the CEFR, but also the entire reflection that preceded and followed that explanation both in research and practice. To use more metaphorical language, plurilingualism is not to be understood as a patchwork or a quilt of neatly arranged multicolored pieces, but rather as some watercolour painting, in which the different colours merge into one another seamlessly to create something unique.

Beyond the problem of conflating constructs, there is another worrying issue: that of negating the very existence of languages, discredited as invented (Makoni \& Pennycook, 2006). Taking this position to the extreme, García and Otheguy (2014) and Otheguy et al. (2015) admit only the existence of individual "idiolects" and completely reject the existence of languages as discrete entities. However, historically what has been invented is the categorization of languages, the boundaries between them, the sacred nature of the norm, not languages themselves (Piccardo, 2017), which have shaped themselves over time in relation to geographic, economic, socio-political, and cultural forces. Languages are complex phenomena that need to be unpacked rather than negated. As MacSwan (2017) aptly reminds us: "Unpacking the ambiguity in the term language ... helps us recognize the inherent sociopolitical nature of named languages, or E-languages, while still recognizing the linguistic reality of language diversity in the form of I-languages, or individual languages" (p. 176). While I agree that languages cannot be considered as entities that exist independently from their speakers, as an abstract, static or idealized concept, the 
convention of named languages helps to investigate transformation and variability over time, shifts in language use, sociopolitical implications and power dynamics of linguistic usages, as well as the cognitive and social development of individual linguistic repertoires. A major conceptual shift towards the verbal form "languaging" as the main term, in line with developments in sociocultural theory (Cowley \& Gahrn-Andersen, 2019; Swain, 2006; Swain, Kinnear, \& Steinman, 2015), does not deny the usefulness of the noun "language", which is the temporary linguistic system that has structured itself through the usage of related speech communities at any given time.

As Cummins (2017) explains:

García and Wei's (2014) dismissal of the construct of language/languages as illegitimate goes beyond the generally accepted claim that languages are socially constructed with fluid, permeable, and arbitrary boundaries. Although languages are certainly processed cognitively in dynamic and integrated ways, languages, as social constructions, do exist [emphasis added] in the lives and experiences of teachers, students, governments, politicians, and countless agencies, and they generate an immense material and symbolic reality. (p. 414)

Not only is the dismissal of any named languages in favour of an exclusive conceptualization of "idiolects" problematic; equally problematic is the extreme vision of the same scholars that each individual possesses a unitary system where no features can be related to any named languages. This appears at odds with the very idea of translanguaging, which, semantically speaking, inevitably emphasises movement from one language to the other, rather than presenting an undifferentiated unitary vision, in which languages are denied any existence. This idea of consciously and responsibly switching between languages that appeared in earlier explanations of translanguaging as pedagogic scaffolding (García, 2009) has recently been dismissed in favour of focussing exclusively on one semantic value of the prefix "trans-", i.e., to go beyond, and by neglecting the value of "across" (Vogel \& García, 2017, p. 3).

These extreme positions have been challenged from a linguistic perspective and from a mainly educational one. The former (MacSwan, 2017) proposes an integrated multilingual model that posits that bilinguals have a single system with many shared grammatical resources but with some internal languagespecific differentiation as well; the latter (Cummins, 2017) proposes:

the term active bilingualism; that endorses the legitimacy of dynamic heteroglossic conceptions of bi/multilingualism, or the understanding that languages are intertwined in complex ways in the minds of multilingual individuals, in ways that reinforce the importance of teaching for two-way transfer across languages. (p. 406)

In the present crusade for the term "translanguaging", the main problem, as Cummins points out, is a tendency to load the constructs concerned "with ex- 
traneous conceptual baggage" (2017, p. 405) that is not intrinsic to their meaning. At the same time, the concept of plurilingualism has been attacked on dubious grounds - that it would adopt an additive monolingual perspective (Garcia \& Wei, 2014); that it would serve the interests of a neo-liberal world order (Flores, 2013) — and has slowly been dismissed, while it was previously considered a rich and enlightening concept, as mentioned above (Canagarajah \& Liyanage, 2012; García, Bartlett, \& Kleifgen, 2007).

\section{A holistic, dynamic repertoire}

As a matter of fact, the distinction between plurilingualism and multilingualism, keeping intact all its potential as plurality of languages, is not to be equated per se with cognitive or social benefits. Thus, such a clear, comprehensive terminological option can be functionally very useful to both scholars and educators. As Cummins (2007) warned, in talking about the two solitudes of French and English in the Canadian French immersion program, it is possible, and unfortunately common, to adopt a monoglossic lens toward the study of languages. Similarly, one can speak more than one language without being plurilingual. Too often learners have been trained to keep their languages completely separate from one another, almost pretending to be a different person in each language, in the pursuit of the chimeric native speaker model. This type of educational policy generally leads to high levels of frustration and feelings of inadequacy and consequent avoidance of the language - even in regions that are officially bilingual (see, for example, Puozzo Capron, 2014). The heteroglossic lens that plurilingualism adopts "permits combinations and alternations of different kinds" (Council of Europe, 2001, p. 134). Thus, plurilinguals, "rather than being condemned to some original division against themselves, can draw strength from the flexibility and versatility afforded by their various languages" (Kramsch, 2009, p. 195). Thus, being plurilingual is primarily a question of attitude, openness, and awareness (Piccardo, 2017):

Plurilingualism ... focuses on the relationships between the languages an individual speaks, the underlying linguistic mechanisms and cultural connotations, the personal linguistic and cultural trajectory as well as the person's attitude toward language diversity, stressing openness, curiosity, and flexibility. (para. 6)

It is precisely this attitude that is at the core of plurilingualism. Thus, some people can be plurilingual without being fluent in any other language due to the different registers and/or varieties of their L1. On the other hand, albeit more seldom, others can be monolingual even if they are fluent in two or more languages. How can this happen? Seeing each language as a polisystem (Wandruszka, 1979) does not happen automatically. People hardly ever realize that the language(s) they speak (their idiolect) present(s) specific individual pat- 
terns, which vary over time and according to their own life trajectory. Also, they often do not realize that all named languages are essentially composita (Wandruszka, 1979):

in the same way as archeological sites show different cultures and their influences, superimposed or harmoniously integrated; however, unlike archeological sites, languages are neither static nor achieved. They are dynamic and flexible, accepting of further contact with other languages, and in a continuous process of creation and modification. (Piccardo, 2013, p. 605)

Plurilingual and pluricultural competence is thus "not the superposition or juxtaposition of distinct competences, but rather the existence of a complex or even composite competence on which the user may draw" (Council of Europe, 2001, p. 168). In a plurilingual approach, the relationship and interaction between languages is central. When one learns a language, one acquires awareness of several other languages. Plurilingualism posits a single, holistic, fluid, dynamic repertoire that one navigates inside according to the context. This is not dissimilar to the concept of "multi-competence" (Cook, 1991; Cook \& Wei, 2016), which also challenges the notions of "native speaker" and of the separation of languages in the brain. In fact, one navigates in this way even within a single language like the mother tongue - varying registers according to domains of use and personal relationships. It is the same process whether the subject is registers, varieties or languages. These all form part of a holistic, linguistic/cultural stock that is available for use, dependent on the circumstances and one's life trajectory.

Depending on several factors such as family history, mobility experience, career path, reading, hobbies, etc., the type of imbalance in the plurilingual profile will alter. Plurilinguals tend to develop a greater proficiency in one language than in others so that the profile of competence in each language is different. This is a dynamic process with a set of varying, partial competence: some parts get rusty; other parts become more developed (Coste, 2014):

The plurilingualism sought is not that of an exceptional polyglot but rather that of ordinary individuals with a varied linguistic capital in which partial competences have their place. What is expected is not maximum proficiency but a range of language skills and receptiveness to cultural diversity. (p. 22)

Plurilingualism stresses the fact that an individual develops through the complex interaction of all available resources: cognitive, emotional, linguistic, and cultural. In fact (Council of Europe, 2001):

The various cultures ... to which that person has gained access do not simply co-exist side by side; they are compared, contrasted and actively interact to produce an enriched, integrated pluricultural competence, of which plurilingual competence is one component, again interacting with other components. (p. 6) 


\section{The dynamic nature of plurilingualism: Mediation and plurilanguaging}

Plurilingualism is not at all additive; it is dynamic and transforming. Plurilingualism situates itself in a sociolinguistic perspective that does not deny the existence of named languages but rather sees them as living phenomena, constantly undergoing transformations, both top down through the different socio-political forces and policies and bottom up through the situated use of individuals engaged in different kinds of socioculturally connotated discourse. It embraces a complex and dynamic vision of language construction with a focus on linguistic and cultural repertoires of individuals seen as agents that are constantly changing in relation to all their experiences and interactions with other agents within changing contexts.

These individuals are constantly mediating: to (co-)construct meaning, to enable communication beyond linguistic and cultural barriers, to make sense of a text. They are mediating across languages as well as within languages, as plurilingualism recognizes variation of languages in a fractal configuration. Mediation is a core concept in language education - especially but not exclusively for the sociocultural theory (Lantolf, 2000, 2007; Schneuwly 2008) and in other fields like sociology, philosophy and psychology, since it helps conceptualize the dynamic nature of social phenomena, human communication and knowledge formation. A discussion on the nature of mediation is certainly beyond the scope of this article. However mediation in its different forms has been the main focus of the CEFRCV. A detailed discussion of the perspective adopted to conceptualize mediation to inform the descriptor development can be found in North and Piccardo (2016). What I wish to highlight here is that mediation is at the core of plurilingualism, as plurilingualism cannot exist without some form of mediation. This centrality of mediation becomes even more visible considering what happens in a plurilingual perspective. Mediation calls for a focus on what plurilingual people do, in other words "plurilanguaging" (Lüdi, Höchle Meier, \& Yanaprasart, 2013; Piccardo, 2017).

The term "plurilanguaging" has been defined as "a dynamic, never-ending process to make meaning using different linguistic and semiotic resources" (Piccardo, 2018, p. 9) and has been used to describe the results of the fascinating and empowering process of negotiation of linguistic and cultural meaning enabled by the exploitation of common scripts and awareness of possible synergies between different and partial linguistic resources used as building blocks (Lüdi, 2011; Lüdi et al., 2013, 2016). Plurilanguaging well describes "the ongoing social process which involves a mobilization of diverse linguistic resources" (Makoni \& Makoni, 2010, p. 261). Piccardo (2017) breaks down the process of plurilanguaging into the following five points: 
1. A cyclical, emergent process of exploring and constructing, which builds on all available resources, both linguistic and cultural. This reminds us that in a complex perspective learning a language is a two way process of interaction and changes between the user/learner and the environment, both being complex adaptive systems (CAS). In a fractal mode, the process of change can be upscaled with an impact on named languages.

2. An agentic process of selecting and (self-)organizing. Individuals seen as CAS, draw upon all their linguistic and cultural resources to mediate and (co-)construct meaning within their material and symbolic world. In this, they, as CAS, undergo a process of reorganization that helps them to reach a new stage in the learning process, i.e., a new state of balance. In a plurilingual view, this process is enhanced by the wealth of stimuli and the need to constantly make targeted decisions.

3. A process of dealing with chaos. These individuals/CAS are not afraid of chaos, as they know it is a necessary transitory phase to reach a new state of balance. They see it as a natural, positive state in which they can feel free and encouraged to use all their linguistic and cultural resources in a personal and creative way.

4. An awareness-raising process that enhances perception. Awareness is the enabling condition to engage with situated stimuli and resources, with the affordances of the environment. It is also developmental so that further awareness of linguistic and cultural features can boost the entire learning process.

5. An empowering process in relation to norms. All the dynamic and transformative processes that a plurilingual perspective sparks makes individuals less concerned with barriers and norms. They tend to see beyond obstacles, to be flexible and ready to cross boundaries in creative ways.

Plurilingual and pluricultural competence is thus a worthwhile educational goal. The enrichment of the linguistic and cultural repertoire creates a new level of awareness that has a positive influence on the development of skills in all languages, including the mother tongue(s), as well as on overall personal development. The new horizons that a plurilingual perspective opens, with mediation at its core, called for tools that help practitioners to venture into this new land. The CEFRCV project was developed in this spirit.

\section{Descriptors for plurilingual and pluricultural competence}

The multidimensional view of communicative language proficiency is illustrated by the CEFR with a wealth of descriptor scales. This is of particular importance for plurilingual and pluricultural competence since, as mentioned 
above, profiles of language ability may be very different in different languages. However, in the CEFR 2001 edition, there were no descriptors for mediation or plurilingual and pluricultural competence because the concepts had only just been developed. Now, the CEFRCV adds validated, calibrated CEFR descriptors for these areas suitable for different levels.

The 2014-17 project to extend the CEFR descriptors is briefly explained in the CEFRCV itself, with a more detailed rationale and account in North and Piccardo (2016). The project first updated the existing scales and then moved on to develop a total of nearly 30 new descriptor scales for aspects of mediation (mediating texts, mediating concepts, mediating communication), for online interaction, and for plurilingual/pluricultural competence. Mediation can be taking place within a single language, variety or register or across them, thus naturally opening up to a plurilingual and pluricultural perspective. The three scales for mediating communication all clearly involve an element of pluricultural competence, especially the scale for Facilitating pluricultural space. In addition, there are three scales specifically for aspects of plurilingual and pluricultural competence. An example descriptor for Level B2 for each of these three scales is given below (Council of Europe, 2018a):

- Plurilingual comprehension: Can use his/her knowledge of contrasting genre conventions and textual patterns in languages in his/her plurilingual repertoire in order to support comprehension (p. 160).

- Building on plurilingual repertoire: Can make use of different languages in his/her plurilingual repertoire during collaborative interaction, in order to clarify the nature of a task, the main steps, the decisions to be taken and the outcomes expected (p. 162).

- Building on pluricultural repertoire: Can reflect on and explain particular ways of communicating in his/her own and other cultures, and the risks of misunderstanding they generate (p. 159).

Following a period of development of just over a year, some 190 institutions and 1,300 individuals were involved in the validation process between February 2015 and February 2016. Just under 70 pilots took place from January to July 2017 and a number of more formal case studies are currently underway in the 2018-19 academic year. Teachers have taken different approaches. Many selected descriptors for mediating text and/or mediating concepts (in collaborative groups) and combined these with those for plurilingual and pluricultural competence. The mediation descriptors helped them to design tasks in which plurilanguaging could take place and in which performance could be assessed. One interesting fact is that all the teachers involved chose to use the descriptors of plurilingual and pluricultural competence for goal setting and self-assessment, but not for teacher assessment. 
Some reflections by teachers piloting the plurilingual/pluricultural descriptors included the following: ${ }^{3}$

Teacher A: Above all the activity served to make students and myself aware of the skills and strategies they were using. For students this represented a confidence boost and reinforced the benefits of being plurilingual. They all felt that it represented the kind of situation which they might encounter, in which they would need to use similar strategies and communication skills, and it reinforced the idea that different members of the group could contribute in different ways depending upon their linguistic background.

Teacher B: The activities contributed in raising the learners' and the teachers' awareness regarding the importance of plurilingualism in the learning environment as well as the positive effects of allowing students to translanguage in the classroom.

Teacher $C$ : It greatly stimulates to focus practically on the applied aspects of pluricultural and plurilingual university education ... reveals great methodological gaps in our understanding of what pluricultural and plurilingual education through co-learnt languages is ...

The availability of descriptors of plurilingual and pluricultural competence paired with a robust and articulated collection of descriptors for mediation is a powerful tool to help teachers and students engage in the shift in attitude that plurilingualism requires. While it is relatively easy to discuss the implications and the potential of a plurilingual vision in academic publications, the reality teachers are confronted with in terms of curricula, language policies, and institutional constraints is very challenging when it comes to making space for plurilingualism in their practice. Thus, descriptors that broaden the scope of language teaching and learning to embrace a more dynamic and transformative view of languaging and plurilanguaging have the potential to foster the necessary attitude change called for by plurilingualism.

\section{Conclusion: An inclusive goal for language policy}

Plurilingualism is an inclusive educational and sociopolitical program in pursuit of social justice and openness. The aim of such a holistic approach to language education is to integrate the approaches to the language of schooling, heritage languages, minority languages, modern foreign languages and even classical languages into one coherent policy that values and encourages users/learners to value their own and others' linguistic and cultural diversity.

\footnotetext{
${ }^{3}$ These are original formulations in English on feedback questionaires from teachers who undertook piloting. Teachers were not given pseudonyms; data were simply made anonymous. These are quotes from three of the 66 teachers who participated in the piloting.
} 
Essentially, students should view these languages as a source of enrichment and awareness and as a window onto a wider world.

The combination that a plurilingual approach offers is: (a) general educational value and (b) a means to achieve integration and social justice. This explains why the provision of plurilingual and intercultural education is a high priority for the Council of Europe. As the oldest and largest pan-European institution (47 member states), the Council of Europe's mission is to uphold human rights, democracy, and the rule of law in Europe. Although it does not have the power to make laws or regulations, it has the power to enforce international agreements that member states have reached on various topics. It is no surprise, thus, that at the heart of the Council of Europe stands the European Court of Human Rights, which enforces the European Convention on Human Rights.

In a fast-changing demographic landscape, with a steady increase of migration and of both linguistic and cultural diversity, the aim of providing inclusive access to quality education for all children and of supporting all individuals in the development of their full potential is at the core of the Council's concerns. In spite of the limited financial resources of the Council, the amount of commitment and engagement put into this mission is extraordinary. One example is the work done to support marginalized communities and languages such as the Romani ${ }^{4}$ with resources and guidance that help this language and culture to be valued and for community members to feel part of the European cultural space. In general, through the activities of its Educational Policy Division, the Council provides support for educators, policy makers, curriculum developers, and researchers, as well as providing a space for the sharing and cross-fertilization of ideas, research, and practices. Several guides for the development of plurilingual and intercultural education and for the linguistic integration of adult migrants have been published (see www.coe.int/en/web/ language-policy/home). The recent update of the CEFR, the CEFRCV mentioned above, is a major step towards providing more visibility to mediation and plurilingual and pluricultural competencies. This new tool will hopefully be instrumental in facilitating a shift towards an enhanced democratization of curricula for second/foreign languages, for the language of schooling, and perhaps in turn for other subjects. The latter is not as unlikely as it sounds: already some countries (e.g., Switzerland) are developing holistic curricula for all subjects with aims expressed as descriptors, and the Council of Europe itself has recently published its Reference framework for competences for democratic culture (Barrett, 2016; Council of Europe, 2018b).

\footnotetext{
${ }^{4}$ www.coe.int/en/web/language-policy/romani; qualirom.ecml.at
} 


\section{References}

Auger, N. (2010). Elèves nouvellement arrivés en France: réalités et perspectives pratiques en classe. Paris: Éditions des archives contemporains.

Balboni, P.E. (2015). Le sfide di Babele: Insegnare le lingue nelle società complesse. 4th ed. Torino: UTET Università.

Barrett, M.D. (2016). Competences for democratic culture: Living together as equals in culturally diverse democratic societies. Strasbourg: Council of Europe. rm.coe. int/16806ccc07

Bauman, Z. (2000). Liquid modernity. Cambridge: Polity.

Beacco, J.-C., \& Byram, M. (2007). From linguistic diversity to plurilingual education: Guide for the development of language education policies in Europe. Strasbourg: Council of Europe. rm.coe.int/CoERMPublicCommonSearchServices/ DisplayDCTMContent?documentld=09000016802fc1c4

Beacco J.-C., Byram, M., Cavalli, M., Coste, D., Egli Cuenat, M., Goullier, F., \& Panthier, J. (2016) Guide for the development and implementation of curricula for plurilingual and intercultural education. Strasbourg: Council of Europe. rm.coe.int/CoERMPublicCommonSearchServices/DisplayDCTMContent? documentld=09000016806ae621

Berthoud, A.-C. (Ed.). (1996). VALS/ASLA: Bulletin Suisse de linguistique appliquee [thematic issue: Acquisition des competences discursives dans un contexte plurilingue], 64.

Berthoud, A-C., Grin, F., \& Lüdi, G. (2013) Exploring the dynamics of multilingualism: The DYLAN project. Amsterdam: John Benjamins.

Bigot, V., Bretegnier, A., \& Vasseur, M.-T. (Eds.). (2013). Vers le plurilinguisme? Vingt ans après. Paris: Éditions des archives contemporaines.

Byram M. (2008). From foreign language education to education for intercultural citizenship. Cleveland, UK: Multilingual Matters.

Canagarajah, S. (2009). The plurilingual tradition and the English language in South Asia. AILA Review, 22, 5-22. doi.org/10.1075/aila.22.02can

Canagarajah, S., \& Liyanage, I. (2012). Lessons from pre-colonial multilingualism. In M. Martin-Jones, A. Blackledge, \& A. Creese (Eds.), The Routledge handbook of multilingualism (pp. 49-65). London: Routledge.

Candelier, M., Camilleri-Grima, Castelotti, V., de Pietro, J-F., Lőrincz, I., Meißner, F.-J., Schröder-Sura, A., \& Noguerol, A. (2010). FREPA/CARAP: A framework of reference for pluralistic approaches to languages and cultures (v. 3). Strasbourg: Council of Europe. www.ecml.at/Portals/1/documents/ECML-resources/CARAP-EN. pdf?ver=2018-03-20-120658-443

Cenoz, J. (2013). Defining multilingualism. Annual Review of Applied Linguistics, 33 , $3-18$. 
Cenoz, J., \& Gorter, D. (2013). TESOL Quarterly [thematic issue: Plurilingualism in TESOL], 47, 591-599.

Cook, V.J. (1991). The poverty-of-the-stimulus argument and multi-competence. Second Language Research, 7, 103-117.

Cook, V.J., \& Wei, L. (2016). The Cambridge handbook of linguistic multicompetence. Cambridge: Cambridge University Press.

Corcoll López, C., \& González-Davies, M. (2016). Switching codes in the plurilingual classroom, ELT Journal 70, 67-77.

Coste, D. (2014). Plurilingualism and the challenges of education. In P. Gromes \& H. Wu (Eds.), Plurilingual education: Policies-Practices - Language development (pp. 15-32). Amsterdam: John Benjamins.

Coste, D., Moore, D., \& Zarate, G. (2009). Plurilingual and pluricultural competence: Studies towards a Common European Framework of Reference for language learning and teaching. Strasbourg: Council of Europe, Language Policy Division. (Original French version published 1997). rm.coe.int/168069d29b

Coste, D., \& Hebrard, J. (1991). Le Français dans le Monde: Recherches et applications [thematic issue: Vers le plurilinguisme? École et politique linguistique]. Paris: Hachette.

Council of Europe (CoE). (1996). Modern languages: Learning, teaching, assessment: A Common European Framework of Reference. [Draft 2 of a Framework Proposal; CC-LANG (95) 5 rev. IV]. Strasbourg: Council of Europe. rm.coe.int/ modern-languages-learning-teaching-assessment-a-common-european-framew/1680886e8c

Council of Europe (CoE). (2001). Common European Framework of Reference for Languages: Learning, teaching, assessment. Cambridge: Cambridge University Press. rm.coe.int/1680459f97

Council of Europe (CoE). (2018a). Common European Framework of Reference for Languages: Learning, teaching, assessment. Companion volume with new descriptors. Strasbourg: Council of Europe.

rm.coe.int/cefr-companion-volume-with-new-descriptors-2018/1680787989

Council of Europe (CoE). (2018b). Reference framework of competences for democratic culture (3 vols.). Strasbourg: Council of Europe. www.coe.int/en/web/education/ publications

Cowley, S.J.,\& Gahrn-Andersen, R. (2019). Editorial: Simplexity, languages and human languaging. Language Sciences [thematic issue: Simplexity, agency and language], 71, 4-7. doi.org/10.1016/j.langsci.2018.04.008

Cummins, J. (2007). Rethinking monolingual instructional strategies in multilingual classrooms. Canadian Journal of Applied Linguistics, 10, 221-240.

Cummins, J. (2017). Teaching minoritized students: Are additive approaches legitimate? Harvard Educational Review, 87, 404-425. 
Dacrema, N. (2012). Il 'caso Austria' [The case of Austria]. In I. Putzu \& G. Mazzon (Eds.), Lingue, letterature nazioni: Centri e periferie tra Europa e Mediterraneo (pp. 294-346). Milan: Franco Angeli.

Del Barrio, M.M. (Ed.). (2015). La enseñanza de la intercomprensión a distancia [Distance teaching of intercomprehension]. Madrid: Universidad Complutense de Madrid. eprints.ucm.es/35033/1/ense\%C3\%B1anza\%20valido.pdf

de Mauro, T. (1977). Il plurilinguismo nella società e nella scuola italiana [Plurilingualism in the Italian culture and school]. In R. Simone \& G. Ruggiero (Eds.), Aspetti sociolinguistici dell'Italia contemporanea. Atti dell'VIII Congresso Internazionale di Studi (Vol. I, pp. 87-101). Roma: Bulzoni Editore.

Flores, N. (2013). The unexamined relationship between neoliberalism and plurilingualism: A cautionary tale. TESOL Quarterly, 47, 500-520.

Furlong, A. (2009). The relation of plurilingualism/culturalism to creativity: A matter of perception. International Journal of Multilingualism, 6, 343-368.

Galante, A. (2018). Plurilingual or monolingual? A mixed methods study investigating plurilingual instruction in an EAP program at a Canadian university (Unpublished doctoral dissertation). University of Toronto, Toronto.

García, O. (2009). Bilingual education in the 21st century: A global perspective. Malden: Wiley-Blackwell.

García, O. (2012). Theorizing translanguaging for educators. In C. Celic \& K. Seltzer (Eds.), Translanguaging: A CUNY-NYSIEB guide for educators (pp. 1-6). New York: CUNY-NYSIEB, The Graduate Center, City University of New York. www.cuny-nysieb.org/wp-content/uploads/2016/04/Translanguaging-Guide-March-2013.pdf

García, O., Bartlett, L., \& Kleifgen, J. (2007). From biliteracy to pluriliteracies. In K. Knapp, D. Perrin, \& M. Verspoor (Series Eds.), Handbooks of applied linguistics [HAL]: Vol. 5, P. Auer \& L. Wei (Vol. Eds.), Handbook of multilingualism and multilingual communication (pp. 207-228). Berlin: Mouton de Gruyter.

García, O., \& Kleifgen, J.A. (2010). Educating emergeny bilinguals: Policies, programs, and practices for English language learners. New York: Teachers College Press.

García, O., \& Lin, A. (2017). Translanguaging in bilingual education. In S. May (Series Ed.), Encyclopedia of language and education: Vol. 5, O. García, A. Lin, \& S. May (Vol. Eds.), Bilingual and multilingual education (pp. 117-130). New York: Springer.

García, O., \& Otheguy, R. (2014). Spanish and Hispanic bilingualism. In M. Lacorte (Ed.), The Routledge handbook of Hispanic applied linguistics (pp. 639-658). New York: Routledge.

García, O., \& Sylvan, C.E. (2011). Pedagogies and practices in multilingual classrooms: Singularities in pluralities. Modern Language Journal, 95, 385-400. 
García, O., \& Wei, L. (2014). Translanguaging: Language, bilingualism and education. New York: Palgrave Macmillan.

Herdina, P., \& Jessner, U. (2002). A dynamic model of multilingualism: Perspectives of change in psycholinguistics. Clevedon, UK: Multilingual Matters.

Käufer, S., \& Chemero, A. (2015). Phenomenology: An introduction. Cambridge, UK: Polity Press.

Kramsch, C. (2009). The multilingual subject: What foreign language learners say about their experience and why it matters. Oxford, UK: Oxford University Press.

Lahire, B. (1998). L'Homme pluriel: les ressorts de l'action. Paris: Nathan.

Lantolf, J.P. (Ed.). (2000). Sociocultural theory and second language learning. Oxford: Oxford University Press.

Lantolf, J.P. (2007). Sociocultural theory: A unified approach to L2 learning and teaching. In J. Cummins \& C. Davison (Eds.), International handbook of English language teaching (pp. 692-701). New York: Springer.

Lewis, G., Jones, B., \& Baker, C. (2012). Translanguaging: Developing its conceptualisation and contextualisation. Educational Research and Evaluation, 18, 655-670. doi.org/10.1080/13803611.2012.718490

Lüdi, G. (2011). Vers de nouvelles approches théoriques du langage et du plurilinguisme. Travaux neuchâtelois de linguistique, 53, 47-64.

Lüdi, G. (2014). Dynamics and management of linguistic diversity in companies and institutes of higher education: Results from the DYLAN project. In P. Gromes \& H. Wu (Eds.), Plurilingual education: Policies-practices - language development (pp. 113-138). Amsterdam: John Benjamins.

Lüdi, G., \& Py, B. (2003). Etre bilingue (3rd ed.). Bern: Peter Lang.

Lüdi, G., \& Py, B. (2009). To be or not to be ... a plurilingual speaker. International Journal of Multilingualism, 6, 154-167.

Lüdi, G., Höchle Meier, K., \& Yanaprasart, P. (2013). Multilingualism and diversity management in companies in the Upper Rhine region. In A.-C. Berthoud, F. Grin, \& G. Lüdi (Eds.), Exploring the dynamics of multilingualism: The DYLAN project (pp. 59-82). Amsterdam: John Benjamins.

Lüdi, G., Höchle Meier, K., \& Yanaprasart, P. (2016). Managing plurilingual and intercultural practices in the workplace: The case of multilingual Switzerland. Amsterdam: John Benjamins

MacLennan, H. (1945). Two solitudes. Toronto: Macmillan.

MacSwan, J. (2017). A multilingual perspective on translanguaging. American Educational Research Journal, 54, 167-201. doi.org/10.3102/0002831216683935

Makoni, B., \& Makoni, S. (2010). Multilingual discourses on wheels and public English in Africa: A case for 'vague linguistique'. In J. Maybin \& J. Swann (Eds.), The Routledge companion to English language studies (pp. 258-270). London: Routledge. 
Makoni, S., \& Pennycook, A. (Eds.). (2006). Disinventing and reconstituting languages. Clevedon, UK: Multilingual Matters.

Marshall, S., \& Moore, D. (2018). Plurilingualism amid the panoply of lingualisms: Addressing critiques and misconceptions in education. International Journal of Multilingualism [numéro thématique: Plurilingualism and pluriculturalism: Francophone perspectives in education], 15, 19-34. doi.org/10.1080/14790718.2016.1253699

Moore, D., \& Gajo, L. (2009). Introduction - French voices on plurilingualism and pluriculturalism: Theory, significance and perspectives. International Journal of Multilingualism, 6, 137-153.

Neuner-Anfindsen, S., \& Meima, E. (2016). MAGICC: A project of the EU lifelong learning programme: Modularising multilingual and multicultural academic communication competence. European Journal of Applied Linguistics, 4, 341-347. doi.org/10.1515/eujal-2016-0008

North, B., \& Piccardo, E. (2016). Developing illustrative descriptors of aspects of mediation for the CEFR. Strasbourg, France: Council of Europe. rm.coe.int/ common-european-framework-of-reference-for-languages-learning-teaching/168073ff31

Otheguy, R., García, O., \& Reid, W. (2015). Clarifying translanguaging and deconstructing named languages: A perspective from linguistics. Applied Linguistics Review, 6, 281-307. doi.org/10.1515/applirev-2015-0014

Piccardo, E. (2013). Plurilingualism and curriculum design: Towards a synergic vision. TESOL Quarterly, 47, 600-614.

Piccardo, E. (2017). Plurilingualism as a catalyst for creativity in superdiverse societies: A systemic analysis. Frontiers in Psychology, 8. doi.org/10.3389/fpsyg.2017.02169

Piccardo, E. (2018). Plurilingualism: Vision, conceptualization, and practices. In P. Trifonas \& T. Aravossitas, (Eds.), Handbook of research and practice in heritage language education (pp. 1-19). New York: Springer International.

Piccardo, E. \& North, B. (2019). The action-oriented approach: A dynamic vision of language education. Bristol: Multilingual Matters.

Piccardo, E., \& Puozzo, I. (Eds.). (2015). The Canadian Modern Language Review [thematic issue: From second language pedagogy to the pedagogy of 'plurilingualism': A possible paradigm shift?, 71(4).

Puozzo Capron, I. (2014). Le sentiment d'efficacité personnelle d'élèves dans un contexte plurilingue: le cas du français au secondaire en Vallée d'Aoste. Bern: Peter Lang.

Schneuwly, B. (2008). Vygotski, l'école et l'écriture [Cahiers des sciences de l'éducation 118]. Geneva: Université de Genève, Faculté de psychologie et des sciences de l'éducation. 
Stratilaki, S. (2005). Vers une conception dynamique de la compétence plurilingue: quelques réflexions six ans après. In M.A. Mochet (Ed.), Plurilinguisme et apprentissages: mélanges à Daniel Coste (pp. 155-168). Lyons: École normale supérieure.

Swain, M. (2006) Languaging, agency and collaboration in advanced language proficiency. In H. Byrnes (Ed.), Advanced language learning: The contribution of Halliday and Vygotsky (pp. 95-108). London: Continuum.

Swain, M., Kinnear, P., \& Steinman, L. (2015). Sociocultural theory in second language education: An introduction through narratives (2nd ed.). Bristol: Multilingual Matters.

Trim, J. (2012). The Common European Framework of Reference for Languages and its background. A case study of cultural policies and educational influences. In M. Byram \& L. Parmenter (Eds.), The Common European Framework of Reference: The globalisation of language policy (pp. 14-34). Bristol: Multilingual Matters.

van Lier, L. (2004). The ecology and semiotics of language learning. Dordrecht: Kluwer Academic.

Vogel, S., \& García, O. (2017). Translanguaging. Oxford research encyclopedia of education. doi.org/10.1093/acrefore/9780190264093.013.181

Wandruska, M. (1979). Die Mehrsprachigkeit des Menschen [The Plurilingualism of the Human Being]. Stuttgart: Kohlhammer.

Williams, C. (1996). Secondary education: Teaching in the bilingual situation. In C. Williams, G. Lewis, \& C. Baker (Eds.), The language policy: Taking stock (pp. 39-78). Llangefni, UK: Canolfan Astudiaethau Iaith (CAI) Language Studies Centre. 